\title{
The Effect of Ladders Snakes on Gross Motor and Cognitive Development in Kindergarten
}

\author{
Ana Falera, Siti Masitoh, Sri Setyowati \\ Universitas Negeri Surabaya \\ Surabaya, Indonesia \\ anafalera@gmail.com
}

\begin{abstract}
The purpose of this study is to examine the effect of snakes and ladders on gross and cognitive motor development in kindergarten children in group $B$. This study used a quantitative approach with quasy experimental design with nonequivalent group design research design. Total samples of 64 children were divided into two groups: the experimental class and the control class. Research data obtained from observation and documentation techniques using observation and documentation guidelines for gross and cognitive motor development.The results showed that using snakes and ladders, gross and cognitive motor development of children experienced positive changes. Data analysis was performed using anova and manova test. From the analysis results obtained value of $F$ arithmetic is 4.730 and sig $0.002<0.05$ for the first hypothesis, 7,806 and $0.00<0.05$ for the second hypothesis and Sig 0,000 $<0.05$ for the third hypothesis. Based on the results of the study it can be concluded that snakes and ladders have an effect on gross and cognitive motor development in Kindergarten Group B children.
\end{abstract}

Keywords-Ladder snak; Cognitive; Gross Motor Development

\section{INTRODUCTION}

Children growth and development take place gradually and continuously. Each stage of child growth should be achieved successfully before a child moves to the next stage. The problems that arise in a developmental phase will be an obstacle for the child to complete the task of the next development, and this will have a negative effect on the later stages of development [1].

Permendikbud Number 146 Year 2014 on Curriculum 2013 PAUD states that unit of child development achievement level (STPPA) of each child is different according to age. In accordance with Pestalozzi's theory, there is a sequence in achieving child's development. For example, before a child can run, he/she must be able to walk. If the walking step is not achieved, he/she will not be able to run well and will become obstacles in the future.

Permendikbud number 137 of 2014 on National standarts of PAUD also mentions each scope to be developed in early age children, confidential religion and moral values, physical motoric (gross and fine), cognitive, language, social and arts.
In permendikbud number 137 of 2014, it is explained that gross motoric development program for children is developed by how the teacher understands the needs and provides opportunities and support for children to move, practice gross and soft motor skills and get used to implementing healty life. Availability of places, tools, and time that children can use to practice strength, skill, flexibility, body coordination to achieve kinesthetic maturity and healthy living habits in fun learning process are necessities.

Standard level of child development achievement in Permendikbud [2] which is intended for children aged 5-6 years mentions that children do body movement in a coordinated way to train flexibility, balance, and agility. The indicator developed is to do jumping and jumping in a coordinated and balanced manner. The child is able to throw objects purposefully[3].

Standard level of child development achievement in Permendikbud Number 137 of 2014 for children aged 5-6 years determines that children are able to carry out body movements in a coordinated manner to train flexibility, balance, and agility. The indicator developed is to do jumping and jumping in a coordinated and balanced manner. The child is able to throw objects purposefully[3].

Permendikbud Number 137 of 2014 explains that the cognitive development program asks teachers to understand the basic concepts of knowledge that children can learn, understand how children learn, support children to seek tau, and conduct experiments to seek answers from curiosity. Teachers also have to optimize every space, tools, materials and events that exist in the environment to encourage the maturity of the child's thinking process.

Cognitive development includes learning and problem solving, logical thinking and symbolic thinking. Logical thinking is that children recognize differences, classifications, initiative patterns, plans, and know cause and effect.

In Permendikbud Number 137 Year 2014 there are several standards of achievement level of children according to their age group. This standard of achievement level of children consists of six developmental spheres, namely 
religious and moral, social emotional, physical motoric, cognitive, language and art. For children aged 5-6 years, the standard level of developmental achievement in the scope of cognitive development in recognizing color is to classify objects based on color and recognize $\mathrm{ABCD}-\mathrm{ABCD}$ patterns. Know ABCD-ABCD pattern is the child is able to estimate the next sequence after seeing the pattern of color or pattern of sequence of predefined forms [4].

Snakes and ladders are designed with colorful patterns, so children can learn to make color patterns. The cognitive development in recognizing $\mathrm{ABCD}-\mathrm{ABCD}$ patterns will be trained in snakes and ladder, when the child is familiar with the pattern.

This game makes children learn to jump from one box to another with balanced and coordinated movements. This will train the child's agility and flexibility when moving by jumping or jumping without falling. In throwing a large dice, the child is directed to throw the dice at the teacher then the teacher drops it to the floor to see what number appears. This will train the child to be able to throw in a direction to be captured by the teacher.

Findings relevant to this research is a research conducted by Elthia Ulfa Marenda Adzani Wulan Suci [5] about the influence of snake and ladder game on motor development of coarse and cognitive in the knowledge of self protection of Kindergarten of Group B. Another research conducted by Hapidin Yenina [6] asserts that traditional games can be developed into traditional educational games.

Based on the description that has been mentioned above, is it true that snake and ladder game affects the development of gross and cognitive motor in children? To prove this, the researcher performs a research about the effect of snake and ladder to gross motor and cognitive development in child of kindergarten group B in Ceria cluster, Banyakan Sub District, Kediri Regency.

\section{METHOD}

\section{A. Type And Design Of Research}

This study uses a quantitative approach. The type of research used is experimental research. This research design uses quasi experimental type nonequivalent control group design, that is by dividing one group into two parts [7]. The first group is the experimental group (given the treatment) and the second group is the control group (which is not given treatment). Pretest is done before treatment and posttest is done after being treated so that the pre-treatment and after-treatment conditions can be seen.

In this experimental research, researchers divide the students into two groups: experimental group and control group, both groups have the same characteristics and characteristics. The experimental group received a snake ladder treatment while the control group did not receive snake ladder games, instead picture card game.

\section{B. Research Variables}

The independent variable is a variable that causes, influences or affects the outcome or dependent variable. In this study, the independent variable is snake and ladder game.

Dependent variable is a variable that depends on independent variable. In this study, the dependent variable is gross and cognitive motor development [3]

\section{Population And Sample}

Population in this research is group B of Ceria Kindergarten, Jabon Village ,Banyakan Sub District, Kediri Regency consisting of nine kindergartens. The sample in this study is Dharma Wanita Kindergarten, Jabon as an experimental group and Dharma Wanita Maron Kindergarten as a control group

\section{Place And Time Of Research}

This research was conducted in Dharma Wanita Jabon kindergarten, Jabon Sub District, Banyakan and Dharma Wanita Maron Kindergrarten, Banyakan Sub District, Kediri. Implementation of this research activity is in the even semester of the school year 2017/2018.

\section{E. Data Collection Techniques And Research Instruments}

Data collection techniques used in this study are observation and documentation. Observations made in this study are systematic observations made by researchers using guidelines as an observation instrument. Observation was performed by observing the activities of the child before treatment and after treatment and at the time of giving treatment using game of snake ladder in accordance with the instrument that has been tested for the validity and reliability. Once obtained through research instruments, the data is then processed and analyzed so that the results can be used to answer questions and test the hypothesis.

The documents used are complementary in the form of photographs or video recordings of children's activities during the development process carried out in class. The use of documentation techniques is also used as evidence that all activities for the development of children in the class have been implemented and in accordance with the planning.

The instrument in this study is an observation method with an observation sheet assessment tool. In this study, the validity of the instrument was measured using content validity which was compiled based on the existing program design namely Permendikbud Number 137 of 2014 by testing the validity of the items, each item statement with expert consultation. After testing the validity, the next step is to test reliability. This test is based on Alpha Cronboach $(\alpha)$ obtained with the help of SPSS 22 windows evaluation version.

\section{F. Data Analysis Technique}

In this study, descriptive statistics were used to describe rough and cognitive motor developmental variables by 
performing a snake ladder game. Inferential statistical analysis is used to test hypotheses. Before the analysis was carried out, homogeneity analysis between variants was carried out to test data normality.

This study uses anova data analysis techniques used to test the comparative hypothesis of two average samples when intervals and ratios are formed. Hypothesis test is divided into two, one way and manova test. One way anova test is used to test hypotheses 1 and 2, while manova test is used to test hypothesis 3 . Terms of analysis used are data with homogeny and normal distribution. To find out, homogeneity and normality tests were performed.

\section{RESULT AND DISCUSSION}

Analysis of the validity of gross motoric development of children isshown as follows:

\section{TABLE 4.1 TEST OF GROSS MOTOR VALIDITY}

\begin{tabular}{lc|c|c|c|c} 
& \multicolumn{9}{c}{ Item-Total Statistics } & & \\
& Scale & Scale & & & Cronbach's \\
& Mean if & Variance if & Corrected & Squared & Alpha if \\
& Item & Item & Item-Total & Multiple & Item \\
& Deleted & Deleted & Correlation & Correlation & Deleted \\
\hline Melempar & 2,37 &, 476 &, 794 &, 631 & . \\
\hline Melompat & 2,20 &, 518 &, 794 &, 631 & . \\
\hline
\end{tabular}

SPSS 24 for windows calculation results in table 4.1 shows that the validity test of coarse motoric item coefficients $r$ count value of each item that will be compared with $\mathrm{r}$ table obtained through a significance level of 0.05 shows $r$ table value $=0.334$. Based on Pearson correlation value, the values for gross motoric item 1 is 0.794 , gross motoric item 2 is 0.794. All items are more than $\mathrm{r}$ table 0.334 . therefore, instrument of gross motor variable research is valid.

\section{TABLE 4.2 COGNITIVE VALIDITY TEST}

\begin{tabular}{cc|c|c|c|c}
\multicolumn{7}{c}{$\begin{array}{c}\text { Scale } \\
\text { Mean if } \\
\text { Item } \\
\text { Deleted }\end{array}$} & $\begin{array}{c}\text { Scale } \\
\text { Variance } \\
\text { if Item } \\
\text { Deleted }\end{array}$ & $\begin{array}{c}\text { Corrected } \\
\text { Item-Total } \\
\text { Correlation }\end{array}$ & $\begin{array}{c}\text { Squared } \\
\text { Multiple } \\
\text { Correlation }\end{array}$ & $\begin{array}{c}\text { Cronbach's Alpha } \\
\text { if Item Deleted }\end{array}$ \\
\hline Merah & 8,77 & 4,358 &, 875 &, 830 &, 868 \\
\hline Biru & 8,77 & 5,182 &, 663 &, 796 &, 912 \\
\hline Hijau & 8,71 & 4,092 &, 870 &, 981 &, 868 \\
\hline Kuning & 8,77 & 5,299 &, 606 &, 640 &, 921 \\
\hline Pola & 8,74 & 3,961 &, 879 &, 984 &, 867 \\
\hline
\end{tabular}

SPSS 24 for windows calculation results in table 4.2 shows that validity test of cognitive variable items can be seen from the coefficient of $r$ count of each item that will be compared with $r$ table, obtained through a significance level of 0.05 where $r$ table value $=0.334$. Based on pearson correlation value, the value for cognitive item 1 is 0.875 , cognitive 2 is 0.663 , cognitive 3 is 0.870 , cognitive 4 is 0.606 , cognitive 5 is 0.879 . All items are more than $r$ table 0.334 . Thus, cognitive variable research instrument is valid.

\section{TABLE 4.3 TEST OF ROUGH MOTOR RELIABILITY}

\begin{tabular}{c|c|c} 
& \multicolumn{1}{c}{$\begin{array}{c}\text { Reliability Statistics } \\
\text { Cronbach's Alpha Based on } \\
\text { Standardized Items }\end{array}$} & N of Items \\
\hline Cronbach's Alpha &, 885 & 2 \\
\hline, 885 &, 85 & 2 \\
\hline
\end{tabular}

Based on the calculation of SPSS in Table 4.3 Cronbach Alpha value is equal to $0.885>\mathrm{r}$ table. Thus, all gross motor variable items are reliable.

\section{TABLE 4.4 COGNITIVE RELIABILITY TESTS}

Reliability Statistics

Cronbach's Alpha Based on

\begin{tabular}{c|cc} 
Cronbach's Alpha & Standardized Items & N of Items \\
\hline, 910 &, 909 & 5 \\
\hline
\end{tabular}

Based on the calculation of SPSS in Table 4.4 Cronbach Alpha value is equal to $0.910>r$ table. Thus, all of these cognitive variable items are reliable.

\section{TABEL 4.5 HASIL PENGUJIAN NORMALITAS MOTORIK} KASAR

One-Sample Kolmogorov-Smirnov Test

Posttest Motorik Kas ar

\begin{tabular}{|c|c|c|}
\hline \multicolumn{2}{|l|}{$\mathrm{N}$} & 33 \\
\hline \multirow{2}{*}{ Normal Parameters ${ }^{\mathrm{a}, \mathrm{b}}$} & Mean & 6,64 \\
\hline & Std. Deviation & 1,084 \\
\hline \multirow{3}{*}{$\begin{array}{l}\text { Most } \\
\text { Differences }\end{array}$} & eAbsolute &, 177 \\
\hline & Positive &, 176 \\
\hline & Negative &,- 177 \\
\hline \multicolumn{2}{|l|}{ Test Statistic } &, 177 \\
\hline \multicolumn{2}{|l|}{ Asymp. Sig. (2-tailed) } &, $010^{\circ}$ \\
\hline
\end{tabular}

a. Test distribution is Normal.

b. Calculated from data.

c. Lilliefors Significance Correction.

Figure 4.5 shows that the significance is, $010>$ Asymp.sig. (2-tailed) of 0.05 . Thus it can be concluded that $\mathrm{H} 0$ is accepted and $\mathrm{H} 1$ is rejected, thus, gross motor residual is normally distributed.

\section{TABEL 4.6 HASIL PENGUJIAN NORMALITAS KOGNITIF}

One-Sample Kolmogorov-Smirnov Test

\begin{tabular}{llr}
\hline N & & Posttest_Kognitif \\
\hline Normal Parameters & & 33 \\
\hline Most Extreme Differences & Mean & 18,45 \\
\cline { 2 - 3 } & Std. Deviation & 1,092 \\
\cline { 2 - 3 } & Absolute &, 176 \\
\cline { 2 - 3 } & Positive &, 176 \\
\cline { 2 - 3 } & Negative &,- 176 \\
\hline Test Statistic & &, 176 \\
\hline Asymp. Sig. (2-tailed) & & \\
\hline $\begin{array}{l}\text { a. Test distribution is Normal. } \\
\text { b. Calculated from data. }\end{array}$ & \\
c. Lilliefors Significance Correction. &
\end{tabular}

Figure 4.6 shows that Significance of .011> Asymp.sig. (2-tailed) of 0.05 . Thus it can be concluded that $\mathrm{H} 0$ is 
accepted and $\mathrm{H} 1$ is rejected, thus, cognitive residual is normally distributed.

\section{TABLE 4.7 TEST OF GROSS MOTOR HOMOGENEITY}

\begin{tabular}{c|c|c|c}
\multicolumn{4}{c}{ Test of Homogeneity of Variances } \\
Posttest_Motorik_Kasar \\
Levene Statistic & df1 & df2 & Sig. \\
\hline, 058 & 1 & 62 &, 811 \\
\hline
\end{tabular}

Table 4.7 shows that the statistical levena values for the experimental class and the control class produce significant values, 058 ( $\mathrm{sig}>0.05$ ), thus, there is no difference in variance between sample groups, in other words the variance between groups is the same or homogeneous. 6

\section{TABLE 4.8 COGNITIVE HOMOGENEITY TEST}

\begin{tabular}{c|c|c|c} 
Test of Homogeneity of Variances \\
$\begin{array}{c}\text { Posttest_Kognitif } \\
\text { df1 }\end{array}$ & df2 & Sig. \\
\hline Levene Statistic & 1 & 62 &, 572 \\
\hline, 323 & 1 & 62 & \\
\hline
\end{tabular}

Based on Table 4.8, levena statistics for the experimental class and control class produce significant value, 323 ( $\mathrm{sig}>0.05$ ) so there is no variant difference between sample groups, in other words the variant between groups is the same or homogeneous.

TABLE 4.9 GROSS MOTOR TEST BETWEEN EXPERIMENT CLASS AND CONTROL CLASS

\begin{tabular}{cc|c|c|c|c}
\multicolumn{7}{c}{ ANOVA } \\
& $\begin{array}{c}\text { Nama } \\
\text { Sum of } \\
\text { Squares }\end{array}$ & df & $\begin{array}{c}\text { Mean } \\
\text { Square }\end{array}$ & F & Sig. \\
\hline Between Groups & 3,881 & 4 &, 970 & 4,730 &, 002 \\
\hline Within Groups & 12,103 & 59 &, 205 & & \\
\hline
\end{tabular}

Based on the result of one way anova test in table 4.9, the value of $F$ arithmetic is 4,730 and the value of significance or $\mathrm{p}$ value $0,002<0,05$. H0 rejected and $\mathrm{Ha}$ accepted, so snake and ladder influences gross motor development of children.

TABLE 4.10 COGNITIVE TEST BETWEEN EXPERIMENT CLASS AND CONTROL CLASS

\begin{tabular}{lc|c|c|c|c} 
ANOVA & \multicolumn{2}{c}{ Nama } \\
& $\begin{array}{c}\text { Sum of } \\
\text { Squares }\end{array}$ & df & Mean & & \\
& Square & F & Sig. \\
\hline Between Groups & 6,430 & 5 & 1,286 & 7,806 &, 000 \\
\hline Within Groups & 9,555 & 58 &, 165 & & \\
\hline
\end{tabular}

Based on the test results one way anova in table 4:10, the value of $F$ arithmetic of 7.806 and the value of significance or $\mathrm{p}$ value $0,000<0.05$. H0 rejected and $\mathrm{Ha}$ accepted, so snake and ladder influences cognitive development of child.
TABLE 4.11 GROSS MOTOR AN COGNITIVE TEST BETWEEN EXPERIMENT CLASS AND CONTROL CLASS

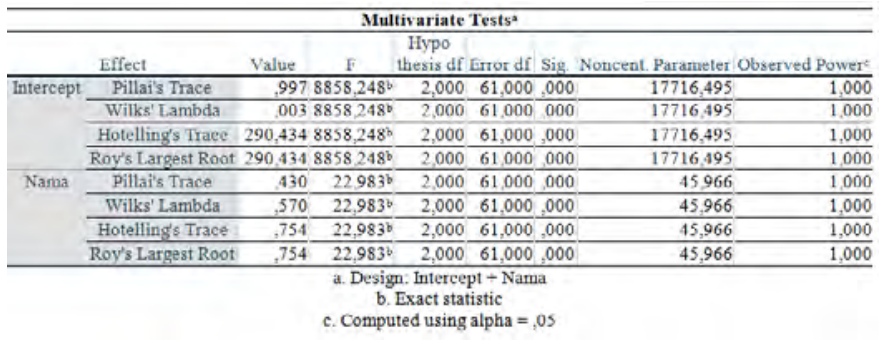

Based on manova test results in table 4.11 that the calculated $F$ value for Pillai's Trace, Wilks' Lambda, Hotelling's Trace, Roy's Largest Root has a significance value or $\mathrm{p}$ value of $0.000<0.05$, thus, snake ladder games affect gross motor and cognitive development in children.

\section{CONCLUSION}

There is an effect of snake and ladder games on motor development rough children aged five to six years in the deep Kediri District this is done in the experimental class, namely Dharma Wanita Kindergarten Jabon. This is known from the differences in the initial assessment result (pretest) with the results of the final assessment (posttest). In the experimental class given the snake ladder game treatment, the posttest results experienced change in results compared to the results of the pretest. Therefore the first hypothesis of the study states the game snakes and ladders effect on gross motoric development of children is proven the truth.

There is influence of snake ladder games on cognitive development five to six year olds in Kediri Regency in this case conducted research in the experimental class, namely Dharma Wanita Jabon Kindergarten.It is known from the difference in the results of the initial assessment (pretest) with the final assessment result (posttest). In the experimental class given snake ladder game treatment, the posttest results experienced change in results compared to the results of the pretest. Thus the second hypothesis of the study states that snakes and ladders play an effect on children's cognitive development is proven to be true.

\section{REFERENCES}

[1] M. Ulfah, “Suyadi. 2013,” Konsep Dasar PAUD.

[2] R. I. Permendikbud, "Peraturan Menteri Pendidikan dan Kebudayaan Republik Indonesia Nomor 137 Tahun 2014 Tentang Standar Nasional Pendidikan Anak Usia Dini.” Jakarta: Mendiknas, 2014.

[3] D. L. Gallahue and J. C. Ozmun, "Understanding Motor Development; Infants, Children, Adolescencents, Adult." United States of America: The McGraw-Hill Companies, Inc, 1998.

[4] M. I. Pratiwi, "STUDI KEMAMPUAN MENGENAL POLA ABCDABCD PADA ANAK KELOMPOK B DI TK SE-GUGUS 3 KECAMATAN KASIHAN," Pendidik. Guru PAUD S-1, vol. 6, no. 1, pp. 56-64, 2017.

[5] Ulfa Marenda Adzani WulanSuci, "No Title," Pengaruh Permainan Ular Tangga Aku Anak Berani terhadap Perkemb. Mot. Kasar dan Kogn. dalam Pengetah. Perlindungan Diri Anak TK Kelompok B., 2017. 
[6] H. HAPIDIN and Y. YENINA, "Pengembangan Model Permainan Tradisional Dalam Membangun Karakter Anak Usia Dini," J. Pendidik. USIA DINI, vol. 10, no. 2, pp. 201-212, 2016.
[7] J. W. Creswell, "Research design," Qual. Quant. Approach. Thousand Oaks SagePublications, 1996. 